Gut, 1988, 29, 762-768

\title{
Intramural distribution of regulatory peptides in the sigmoid-recto-anal region of the human gut
}

\author{
G-L FERRI, T E ADRIAN, JANET M ALLEN, L SOIMERO, \\ ALESSANDRA CANCELLIERI, JANE C YEATS, MARION BLANK, \\ JULIA M POLAK, AND S R BLOOM \\ From the Department of Anatomy, 'Tor Vergata' University, Rome, Italy and Departments of Medicine and \\ Histochemistry, RPMS, Hammersmith Hospital, London
}

SUMmARY The distribution of regulatory peptides was studied in the separated mucosa, submucosa and muscularis externa taken at 10 sampling sites encompassing the whole human sigmoid colon (five sites), rectum (two sites), and anal canal (three sites). Consistently high concentrations of VIP were measured in the muscle layer at most sites (proximal sigmoid: 286 (16) pmol/g, upper rectum: 269 (17), a moderate decrease being found in the distal smooth sphincter (151 (30) pmol/g). Values are expressed as mean (SE). Conversely, substance $P$ concentrations showed an obvious decline in the recto-anal muscle (mid sigmoid: $19(2 \cdot 0) \mathrm{pmol} / \mathrm{g}$, distal rectum: 7.1 (1.3), upper anal canal: 1.6 $(0 \cdot 6))$. Somatostatin was mainly present in the sigmoid mucosa and submucosa $(37(9 \cdot 3)$ and $15(3 \cdot 5)$ $\mathrm{pmol} / \mathrm{g}$, respectively) and showed low, but consistent concentrations in the muscle (mid sigmoid: $2 \cdot 2$ $(0.7) \mathrm{pmol} / \mathrm{g}$, upper anal canal: $1.5(0 \cdot 8))$. Starting in the distal sigmoid colon, a distinct peak of tissue NPY was revealed, which was most striking in the muscle (of mid sigmoid: $16(3.9) \mathrm{pmol} / \mathrm{g}$, upper rectum: $47(7 \cdot 8)$, anal sphincter: $58(14))$. Peptide YY was confined to the mucosa and showed an earlier peak (upper sigmoid: 709 (186) pmol/g, mid-distal sigmoid: 1965 (484)). A clear differential distribution of regulatory peptides was thus shown in the region studied. A possible role is suggested for NPY and VIP containing nerves in the effector control of the human internal anal sphincter.

The whole region of the human gut composed of the sigmoid colon, rectum and anal canal can probably be considered as a complex regulatory area, devoted to the final processing and expulsion of bowel contents, culminating in defecation. 'In fact, although distinct sphincteric structures are conspicuously absent at this level, the rectosigmoid junction itself has been proposed to act as a regulatory zone. ${ }^{2}$ Below the rectum, a well defined smooth sphincter - that is, the internal anal sphincter, is found at the termination of the alimentary canal.'

Within this complex region, intrinsic nerves appear to play a crucial role. This is clearly the case for the inhibitory control of the internal anal sphincter, exerted by the rectoanal reflex and largely mediated

Address for correspondence: Dr G-I. Ferri, Department of Anatomy. Tor Vergata University, via O. Raimondo. (0)173 Roma, Italy.

Received for publication 4 December 1987 by intramural pathways, ${ }^{3-5}$ which proved to be nonadrenergic, non-cholinergic."

Because little information is available on the peptide containing innervation of this region of the human gut, we have investigated this aspect in detail. At each of 10 sampling sites distributed along the whole region, the main layers of the wall - that is, mucosa, submucosa and muscularis externa, were separated and the concentrations of VIP, substance $P$, somatostatin, NPY, mammalian bombesin and PYY were measured by radioimmunoassay. In view of the immunochemical methods used, results described will refer to peptide like immunoreactivity throughout.

\section{Methods}

Fresh tissues were obtained from six specimens of abdominoperineal resection of the sigmoid colon and 


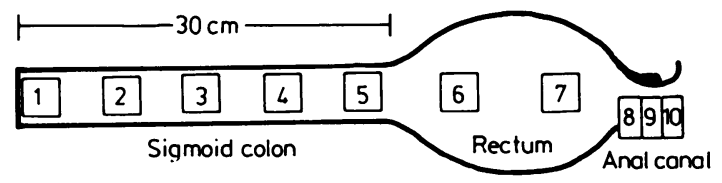

Fig. 1 Sampling plan used in the study. Samples were taken at each of the equidistant sites $1-5$, along the distal $30 \mathrm{~cm}$ of colon-that is, virtually the whole sigmoid. One sample each was taken from the proximal and distal halves of the rectal ampulla (sites 6 and 7 , respectively). Three adjacent strips, 7-9 $\mathrm{mm}$ wide, were taken across the anal canal (sites 8 to 10), the middle one (site 9) terminating at the distal margin of the smooth sphincter.

rectum, because of colonic or rectal carcinoma (patients' mean age 67.5 years, range $61-79$, three men and three women). Only specimens devoid of advanced luminal obstruction and/or proximal dilatation were investigated, while no tissue was taken for the present investigation before sampling for diagnostic histopathology had been completed.

The sampling plan used is summarised in Figure 1. One sample was taken at each of the equidistant sites $1-5$, along the distal $30 \mathrm{~cm}$ of colon (thus virtually covering the whole sigmoid). One sample each was taken from the proximal and distal halves of the rectal ampulla (sites 6 and 7, respectively), thus over $2 \mathrm{~cm}$ away from any other sample. Three adjacent strips, 7-9 $\mathrm{mm}$ wide, were taken across the anal canal (sites 8 to 10), the middle one (site 9) terminating at the distal margin of the smooth sphincter. Thus, the most distal sample (site 10) did not include a smooth muscle layer. As the internal anal sphincter starts as a progressive thickening of the muscle layer in the most distal rectum, without a distinct proximal border,' sites 8 and 9 were considered to include most of it.

Tissue samples $(n=6$, except sites 6 and $7: n=5)$ were taken over $5 \mathrm{~cm}$ away from the tumour margin, free of mesenteric (or epiploic) fat and other structures surrounding the gut wall. Histology was checked in parallel samples, in order to exclude neoplastic infiltration in the vicinity of the processed tissues.

Samples were separated by microdissection into mucosa (containing epithelium and lamina propria), submucosa and muscularis externa, as previously described in detail. ${ }^{7 x}$ From the most distal site (number 10), skin and subjacent connective and/or adipose tissue were obtained in a similar way. For peptide extraction, layers were coarsely chopped with a scalpel, weighed and dropped into preheated polypropylene tubes, containing $0.5 \mathrm{~mol} / \mathrm{l}$ acetic acid (approximately $10 \mathrm{ml} / \mathrm{g}$ ) in a vigorously boiling water bath for 15 minutes. After a further 30 minutes at room temperature (with slow constant agitation), tubes were briefly spun and supernatants were stored frozen $\left(\right.$ at $\left.-70^{\circ} \mathrm{C}\right)$. Radioimmunoassays were per-
Table Antiseraspecificity

\begin{tabular}{llll}
\hline & & Specificity & Reference \\
\hline VIP & V9 & Whole moleculc & $(9)$ \\
Substance P & SP3 & C-terminal & $(9)$ \\
Mammalian bombesin & BN 1033 & C-terminal* $^{*}$ & $(9)$ \\
Somatostatin & K2 & Whole cyclic region & $(9)$ \\
NPY & YN7 & N-terminalt & $(10)$ \\
PYY & Y21 & N-terminal & $(11)$ \\
\hline
\end{tabular}

*the antiserum measures fully whole mammalian bombesin (gastrinreleasing peptide 1-27) and the decapeptide of mammalian bombesin (gastrin-releasing peptide 18-27); tnot cross-reacting

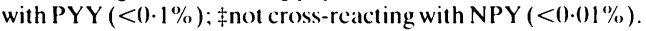

formed as previously described in detail, ${ }^{, 11}$ using the antisera listed in the Table.

\section{Results}

Of the various peptides studied, VIP, substance P, somatostatin and NPY were detected in all three layers, while bombesin was mainly represented in the muscle. Conversely, PYY was virtually confined to the separated mucosa $(99 \cdot 2(0 \cdot 4) \%$ of the total content, mean (SE)). The concentration profile of each peptide is shown in Figs 2-4.

Vasoactive intestinal polypeptide (Fig. 2, left) was most abundant in the separated mucosa at all levels, lower concentrations being shown in the anal skin. Considerable amounts of the same neuropeptide were revealed in the submucosa and muscle layer, too, throughout the extension of the internal anal sphincter. Conversely, substance P (Fig. 2, right) appeared to be little represented beyond the rectum, its muscular concentrations already declining at the distal rectal site.

Somatostatin immunoreactivity (Fig. 3, left) was present mainly in the mucosa and, to a lesser extent, in the submucosa, in which layers it showed a marked decrease in concentration across the rectum. In the muscle layer, this peptide showed much lower, but consistent tissue levels down to the proximal anal canal.

Measurable concentrations of NPY (Fig. 3, right) were found in all layers, with the exception of the mucosa of most of the sigmoid colon (sites 1 to 4 ). A clear increase in NPY concentration was found distally, the lower rectum and anal canal showing a distinct peak, most evident in the muscle. A similarly striking, but earlier, peak was demonstrated for PYY concentrations in the mucosa (Fig. 4, upper panel) between the mid-distal sigmoid and the proximal rectum. Mammalian bombesin (Fig. 4, lower panel) was largely confined to the sigmoid colon, layers other than muscle containing barely detectable amounts of this peptide. 

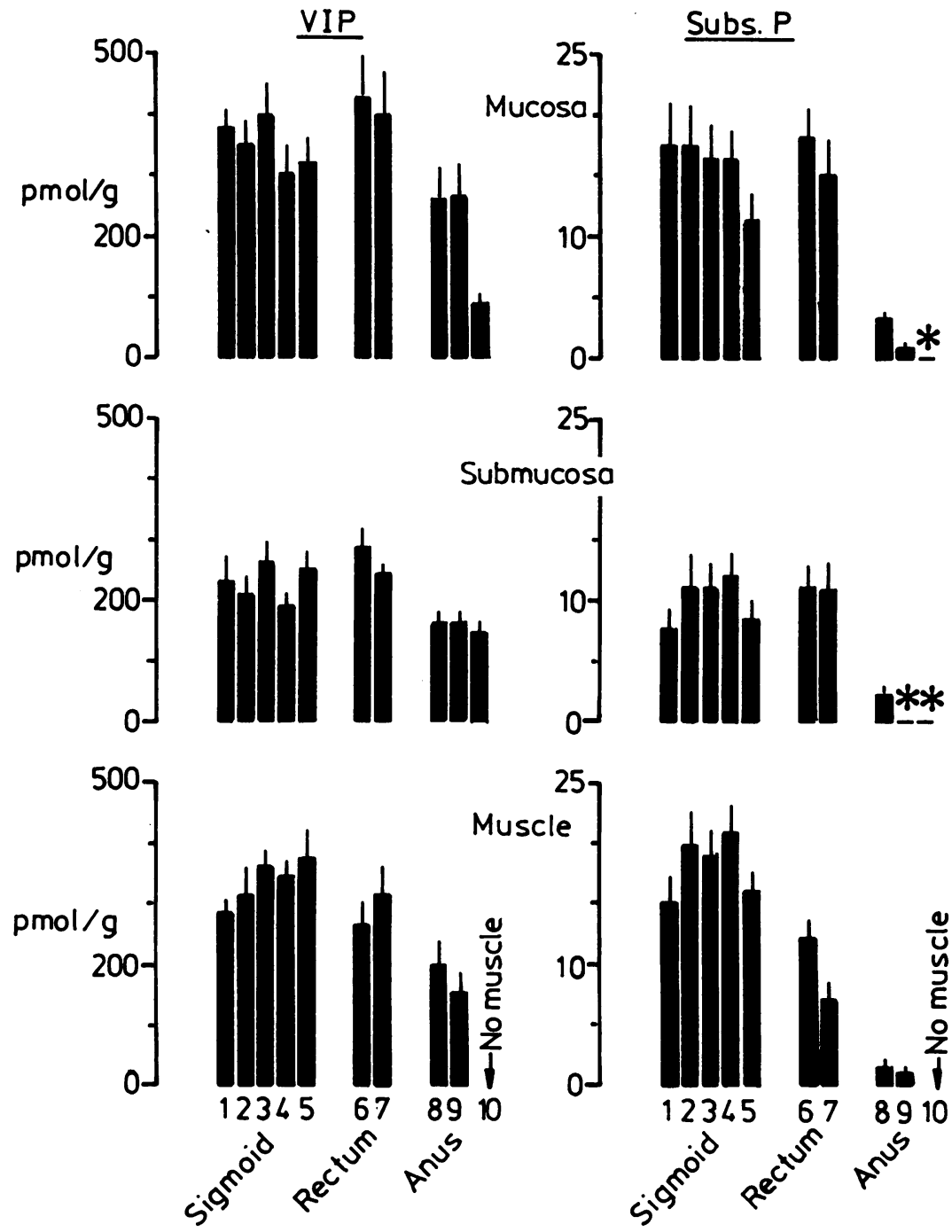

Fig. 2 Concentrations of vasoactive intestinal polypeptide (VIP: left) and substance P (Subs. P: right) in the three separated layers - that is mucosa (containing epithelium and innervated lamina propria), submucosa and muscularis externa (muscle= circular and longitudinal muscle with intervening myenteric plexus) across the sigmoid-recto-anal region (sigmoid=sigmoid colon, anus = anal canal; no distinct muscle layer was present at site 10, which was taken distal to the smooth sphincter; means $(S E) ;^{*}=<1$ pmollg).

\section{Discussion}

A distinct differential distribution of regulatory peptides was shown along the sigmoid-recto-anal region of the human gut. Peptide concentrations measured in the sigmoid colon are largely in keeping with previous human studies, which described the molecular characterisation of the same peptides and their distribution as far down as the colon..$^{71-19}$ Minor differences in somatostatin tissue concentrations, as measured in the human gut by various laboratories ${ }^{77-19}$ are probably due to differing characteristics of the antisera used, or to the varied tissue storage and extraction procedures used.

A previous study, carried out mainly in the cat and not including the internal anal sphincter, concluded that 'a rich VIP nerve supply is characteristic of sphincters'.$^{20}$ As far as peptide distribution may be taken to reflect the density of peptide containing nerves, a comparative abundance of VIP nerves can 

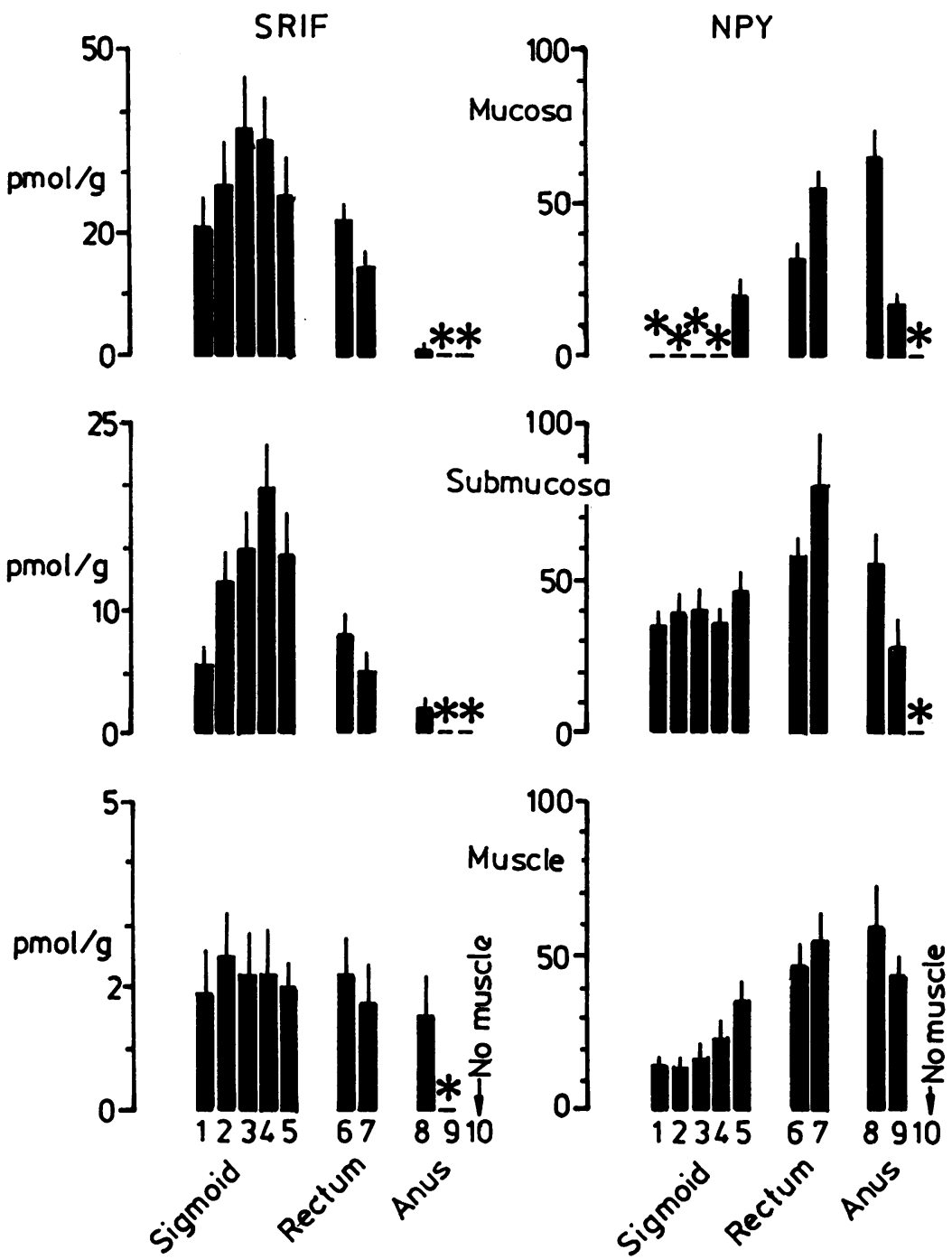

Fig. 3 Concentrations of somatostatin (SRIF: left) and neuropeptide Y (NPY: right) in the three separated layers - that is, mucosa (containing epithelium and innervated lamina propria), submucosa and muscularis externa (muscle =circular and longitudinal muscle with intervening myenteric plexus) across the sigmoid-recto-anal region (sigmoid=sigmoid colon, anus = anal canal; no muscle layer was present at site 10, which was taken distal to the smooth sphincter; means (SE); $*=<0.5$ pmol/g for somatostatin, $<10$ for $N P Y)$.

be stated for the muscle layer in coincidence with the human internal anal sphincter, various other neuropeptides almost disappearing at this level. Species specific patterns, however, may occur, as very low VIP concentrations were shown in the cat anus. ${ }^{21}$ In man, it is worth noting that the pro-enkephalin Aderived peptide Met $^{5}$-enkephalin-arg 6 -gly'-leu too, was little represented beyond the human sigmoid colon. ${ }^{22}$

The presence of VIP and NPY in considerably high concentrations in the muscle layer of the human anal canal may suggest a role for such peptides in the effector control of the smooth anal sphincter. The recto-anal reflex, which inhibits the high intrinsic tone of the internal anal sphincter via a neural nonadrenergic, non-cholinergic mechamism ${ }^{6}$ has been mentioned. Indeed, VIP is well known to relax gut smooth muscle ${ }^{23}$ including that of the internal anal sphincter. ${ }^{24}$ This same peptide has been proposed as a mediator of gut inhibitory nerves ${ }^{25}$ and, specifically, of the recto-anal reflex in the rabbit. ${ }^{26}$

A complex distribution was revealed for NPY in 

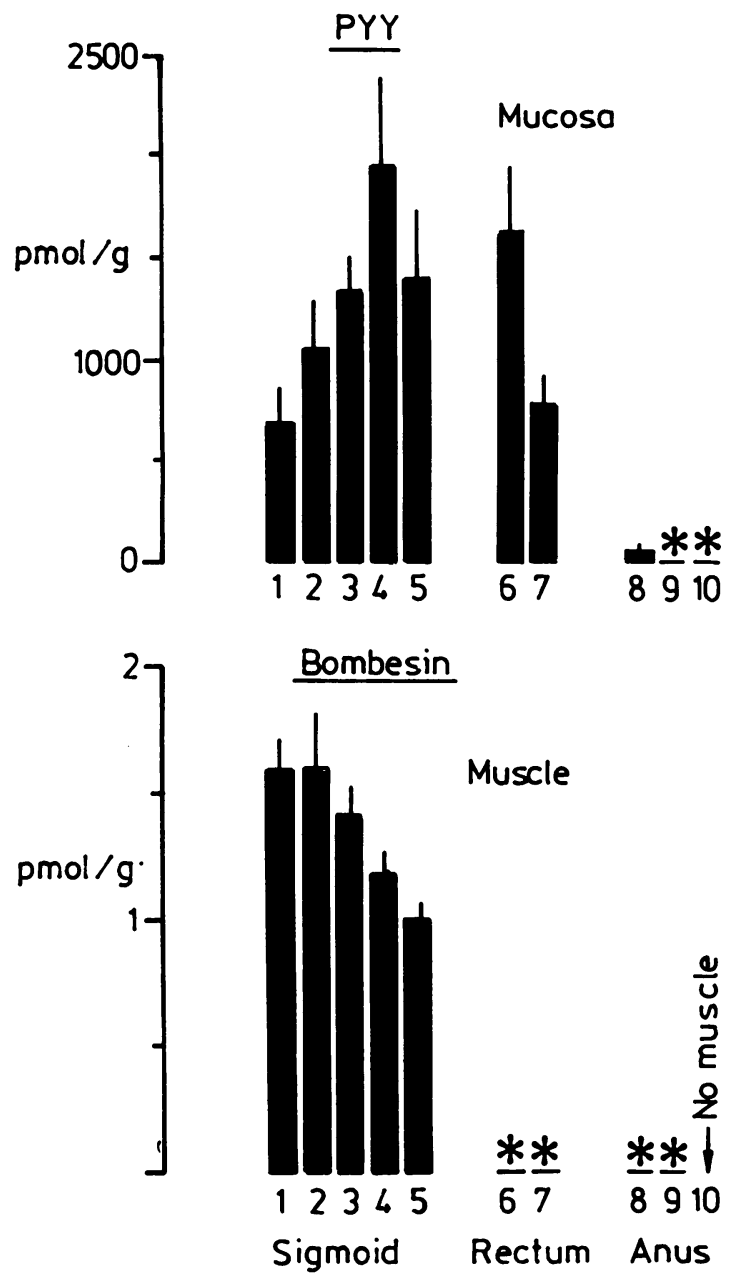

Fig. 4 Concentrations of peptide $Y Y$ in the separated mucosa (PYY, upper panel) and mammalian bombesin in the muscularis externa (muscle = circular and longitudinal muscle with intervening myenteric plexus) across the sigmoid-recto-anal region (sigmoid = sigmoid colon, anus = anal canal; no muscle layer was present at site 10, which was taken distal to the smooth sphincter; means (SE); $*=<1$ pmollg for $P Y Y,<0 \cdot 5$ for mammalian bombesin).

the gut, ${ }^{27-31}$ where it was localised to both intrinsic neurons, which were shown to contain also VIP and PHI like peptides, ${ }^{32}$ and extrinsic nor-adrenergic fibres. As the internal anal sphincter, including that of man, is provided with a very rich supply of noradrenergic nerve fibres, ${ }^{33}$ the high NPY concentration shown in this area may reflect the density of extrinsic sympathetic nerves. NPY has been shown to inhibit contraction of smooth muscle, ${ }^{27} 34$ including that of the gut, ${ }^{35}$ probably through inhibition of cholinergic neurotransmission. ${ }^{356}$ In addition, this peptide has a powerful vasoconstrictory effect, ${ }^{27}$ so that perivascular NPY-fibres may be involved in gut vasomotor control.

The distribution of bombesin like peptides, largely confined to the muscle, confirms previous findings obtained in the human duodenum, jejunum, ileum, and colon. ${ }^{7+37}$ A study has been reported, in which the human gut wall had been split into preparations of mucosa and 'muscle' (the latter apparently also including submucosa), both of which showed similar bombesin concentrations at most levels. ${ }^{38}$ It is relevant to note, however, that human postmorten specimens were used in the latter investigation.

A recent study showed an inhibitory effect of somatostatin on the basal tone of human rectal musculature. ${ }^{39}$ Thus, even the small amounts of somatostatin shown in the rectal muscularis might have a functional significance. The main localisation of this neuroendocrine peptide, however, was shown to be in the endocrine cell containing mucosa, as in other areas of the human gut. ${ }^{7 \times 37}$ Finally, the other endocrine peptide studied - that is, PYY, showed a very clear peak between distal sigmoid and upper rectum. Such finding appears to stress the proposed role of PYY in the distal hormonal inhibition of a variety of digestive functions, including gastric emptying, colonic motility and blood flow. ${ }^{\text {(1) } 13}$

Most specimens were kindly provided by $\mathrm{L}$ Tonelli and $G$ Biliotti, University of Firenze, Italy. The authors are indebted to G Siracusa, A Riva, and V Eusebi for encouragement and stimulation during the progress of this work, to $\mathrm{V}$ Eusebi and $\mathrm{A} \mathrm{M}$ Mancini for laboratory hospitality. Partly supported by an Italian National Research Council (CNR) Research Contract.

\section{References}

1 Reeve DRE. Anatomy of the sphincters of the alimentary canal. In: Thomas PA, Mann CV, eds. Alimentary sphincters and their disorders. London: Macmillan, 1981: 1-26.

2 Baker WNW, Mann CV. The rectosigmoid junction zone: another sphincter? In: Thomas PA, Mann CV, eds. Alimentary sphincters and their disorders. London: Macmillan, 1981: 201-11.

3 Denny-Brown D, Robertson EG. An investigation of the nervous control of defecation. Brain 1935; 58: 256-310.

4 Burleigh DE, D'Mello A. Neural and pharmacologic factors affecting motility of the internal anal sphincter. Gastroenterology 1983; 84: 409-17.

5 Duthie HL. The anal sphincters. In: Thomas PA, Mann $\mathrm{CV}$, eds. Alimentary sphincters and their disorders. London: Macmillan, 1981: 213-26.

6 Bouvier M, Gonella J. Nervous control of the internal anal sphincter of cat. J Physiol 1981; 310: 457-69. 
7 Ferri G-L, Adrian TE, Ghatei MA, et al. Tissue localisation and relative distribution of regulatory peptides in separated layers from the human bowel. Gastroenterology 1983; 84: 777-86.

8 Ferri G-L. Human gut neuroanatomy: methodology for a quantitative analysis of nerve elements and neurotransmitter diversity in the human enteric nervous system. Basic Appl Histochem 1988; 32: 117-44.

9 Bloom SR, Long RG, eds. Radioimmunoassasy of gut regulatory peptides. London: Saunders, 1982.

10) Allen JM, Yeats JC, Adrian TE, Bloom SR. Radioimmunoassay of neuropeptide Y. Regul Pept 1984; 8: $61-70$.

11 Adrian TE, Ferri G-L, Bacarese-Hamilton AJ, Fuessl HS, Polak JM, Bloom SR. Human distribution and release of a putative new gut hormone, peptide YY. Gastroenterology 1985; 89: 1070-7.

12 Holzer P, Bucsics A, Saria A, Lembeck F. A study of the concentrations of substance $P$ and neurotensin in the gastro-intenstinal tract of various mammals. Neuroscience 1982; 7: 2919-24.

13 Brodin E, Sjölund K. Hakanson R. Sundler F. Substance $P$-containing nerve fibres are numerous in human but not in feline intestinal mucosa. Gastroenterology 1983; 85: 557-64.

14 Price J, Penman E, Wass JAH, Rees LH. Bombesin-like immuno-reactivity in human gastrointestinal tract. Regul Pept 1984; 9: 1-10.

15 Llewellyn-Smith IJ, Furness JB, Murphy R, O’Brien $P E$, Costa $M$. Substance P-containing nerves in the human small intestine. Gastroenterology 1984; 86: 421-35.

16 Allen JM, Ferri G-L, Hughes J, Polak JM, Bloom SR. Presence, distribution and effects of neuropeptide $\mathrm{Y}$ in the mammalian gut. Gut 1985; 26: 547 .

17 Penman E, Wass JAH, Butler MG, et al. Distribution and characterisation of immunoreactive somatostatin in human gastro-intestinal tract. Regul Pep 1983; 7: 53-65.

18 Keast JR, Furness JB, Costa M. Somatostatin in human enteric nerves. Cell Tissue Res 1984; 237: 299-308.

19 Baldissera FGA, Holst JJ, Jensen SL, Krarup T. Distribution and molecular forms of peptides containing somatostatin immuno-determinants in extracts from the entire gastrointestinal tract of man and pig. Biochim Biophys Acta 1985; 838: 132-43.

20 Alumets J, Fahrenkrug J, Hakanson R, Schaffalitzky de Muckadell O, Sundler F, Uddman R. A rich VIP nerve supply is characteristic of sphincters. Nature 1979; 280: 155-6.

21 McGregor GP, Bishop AE, Blank MA, et al. Comparative distribution of vasoactive intestinal polypeptide (VIP), substance P and PHI in the enteric sphincters of the cat. Experientia 1984; 40: 469-71.

22 Ferri G-L, Morreale RA, Soimero L, Biliotti G, Dockray GJ. Intra-mural distribution of Metsenkephalin-Arg ${ }^{6}-G^{7}{ }^{7}-$ Leu $^{\times}$in sphincter regions of the human gut. Neurosci Lett 1987; 74: 304-8.

23 Said SI, ed. Vasoactive intestinal peptide. New York: Raven Press, 1982

24 Kubota M, Szurszewski JH. Effect of VIP, PHI, bradykinin and ATP on activity of the canine internal anal sphincter. Gastroenterology 1985; 88: 1458.
25 Fahrenkrug J, Haglund U, Jodal M, Lundgren O, Olbe L. Schaffalitzky de Muckadell OB. Nervous release of vasoactive intestinal polypeptide in the gastrointestinal tract of cats: possible physiological implications. J Physiol 1978; 284: 291-305.

26 Biancani P, Walsh J, Behar J. Vasoactive intestinal peptide: a neurotransmitter for relaxation of the rabbit internal anal sphincter. Gastroenterology 1985; 89: $867-74$.

27 Lundberg JM, Terenius L, Hökfelt T, et al. Neuropeptide Y (NPY)-like immunoreactivity in peripheral noradrenergic neurones and effects of NPY on sympathetic function. Acta Physiol Scand 1982; 116: 477-90.

28 Furness JB, Costa M, Emson PC, et al. Distribution, pathways and reactions to drug treatment of nerves with neuropeptide $\mathrm{Y}$ - and pancreatic polypeptide-like immunoreactivity in the guinea-pig digestive tract. Cell Tissue Res 1983; 234: 71-92.

29 Sundler F, Moghimzadeh E, Hakanson R, Ekelund M, Emson $\mathrm{P}$. Nerve fibres in the gut and pancreas of the rat displaying neuropeptide $\mathrm{Y}$ immunoreactivity. Intrinsic and extrinsic origin. Cell Tissue Res 1983; 230: 487-93.

30) Ferri G-L, Ali-Rachedi A, Tatemoto K, Bloom SR, Polak JM. Immuno-cytochemical localisation of neuropeptide-like immunoreactivity in extrinsic noradrenergic and intrinsic gut neurons. Front Horm Res 1984; 12: 81-4.

31 Lee Y, Shiosaka S, Emson PC, Powell JF, Smith AD, Tohyama M. Neuropeptide Y-like immunoreactive structures in the rat stomach with special reference to the noradrenaline neuron system. Gastroenterology 1985; 89: 118-26.

32 Ekblad E, Hakanson R, Sundler F. VIP and PHI coexist with an NPY-like peptide in intramural neurones of the small intestine. Regul Pept 1984; 10: 47-55.

33 Gabella G. Innervation of the gastrointestinal tract. Int Rev Cytol 1979; 59: 129-93.

34 Allen JM, Adrian TE, Tatemoto K, Polak JM, Hughes J, Bloom SR. Two novel peptides, neuropeptide $Y$ (NPY) and peptide YY (PYY) inhibit the contraction of the electrically stimulated mouse vas deferens. Neuropeptides $1982 ; 3: 71-7$.

35 Allen JM, Hughes J, Bloom SR. Presence, distribution and pharmacological effects of neuropeptide $\mathrm{Y}$ in mammalian gastrointestinal tract. Dig Dis Sci 1987; 32: 506-12.

36 Wiley J, Owyang C. Neuropeptide Y inhibits cholinergic transmission in the isolated guinea pig colon: mediation through alfa-adrenergic receptors. Proc Natl Acad Sci USA 1987; 84: 2047-51.

37 Ferri G-L, Adrian TE, Soimero L, et al. Regulatory peptide distribution in separated layers of the human jejunum. Digestion 1987; 37: 15-21.

38 Greeley GH, Partin M, Spannagel A, et al. Distribution of bombesin-like peptides in the alimentary canal of several vertebrate species. Regul Pept 1986; 16: 169-81.

39 Lerebours E, Weber J, Chayvialle JA, Galmiche JP, Colin R, Denis Ph. Somatostatin effect of rectal muscle in human healthy volunteers. Digestion 1987; 36: 42-6.

40 Lundberg JM, Tatemoto K, Terenius L, et al. Localisation of peptide YY (PYY) in gastrointestinal endocrine 
cells and effects on intestinal blood flow and motility. Proc Natl Acad Sci USA 1982; 79: 4471-5.

41 Suzuki T, Nakaya M, Itoh Z, Tatemoto K, Mutt V. Inhibition of interdigestive contractile activity in the stomach by peptide YY in Heidenhain pouch dogs. Gastroenterology 1983; 85: 114-21.
42 Adrian TE, Savage AP, Sagor GR, et al. Effect of peptide $\mathrm{YY}$ on gastric, pancreatic, and biliary function in humans. Gastroenterology 1985; 89: 494-9.

43 Pappas TN, Debas HT, Chang AM, Taylor IL. Peptide YY release by fatty acids is sufficient to inhibit gastric emptying in dogs. Gastroenterology 1986; 91: 1386-9. 